\title{
Histological, Immunohistological, and Clinical Features of Merkel Cell Carcinoma in Correlation to Merkel Cell Polyomavirus Status
}

\author{
T. Jaeger, J. Ring, and C. Andres \\ Department of Dermatology and Allergy Biederstein, Technische Universität München, 80802 Munich, Germany \\ Correspondence should be addressed to T. Jaeger, tessie.jaeger@gmx.de
}

Received 30 December 2011; Accepted 2 February 2012

Academic Editor: Arash Kimyai-Asadi

Copyright ( 2012 T. Jaeger et al. This is an open access article distributed under the Creative Commons Attribution License, which permits unrestricted use, distribution, and reproduction in any medium, provided the original work is properly cited.

\begin{abstract}
Merkel cell carcinoma is a rare, but highly malignant tumor of the skin with high rates of metastasis and poor survival. Its incidence rate rises and is currently about 0.6/100000/year. Clinical differential diagnoses include basal cell carcinoma, cyst, amelanotic melanoma, lymphoma and atypical fibroxanthoma. In this review article clinical, histopathological and immunhistochemical features of Merkel cell carcinoma are reported. In addition, the role of Merkel cell polyomavirus is discussed.
\end{abstract}

\section{Introduction}

Merkel cell carcinoma (MCC) is one of the most malignant tumors of the skin which affects primarily sun-exposed skin from older Caucasian, predominantly males with a mean age at the time of diagnosis of about 70 years [1]. Its incidence rate rises with immunosuppression [2, 3], and is currently $0.6 / 100000 /$ year [4]. Its biological behavior is highly aggressive with high rates of metastasis and poor survival [1]. If the Merkel cell is the cell of origin of this cancer is still matter of debate. Recently, it was reported that Merkel cells are derived from the epithelial lineage [5]. Besides, because of sarcomatous elements were found in MCC, so a totipotent epithelial stem cell as origin was suggested [6], but further examinations are requested.

\section{Clinical Features}

MCC characteristically develops rapidly and asymptomatically over months [7]. Most MCCs are located on sun-exposed areas. About $50 \%$ of MCCs occur on the head and neck, $40 \%$ on the extremities and remainder on the trunk and genitalia [8]. It very rarely arises on sun-protected areas, such as the oral and genital mucous membranes, where it is characterized by a particularly poor prognosis $[9,10]$.
It usually manifests as solitary, firm, flesh-colored to red nodule with a smooth, shiny surface, sometimes with telangiectasia $[11,12]$. Differential diagnosis includes basal cell carcinoma, cyst, amelanotic melanoma, lymphoma, and atypical fibroxanthoma [13].

The five most common clinical features were used to create an acronym AEIOU [14];

$$
\begin{aligned}
& \text { Asymptomatic/lack of tenderness, } \\
& \text { Expanding rapidly ( } \leq 3 \text { months), } \\
& \text { Immunosuppression, } \\
& \text { Older than age 50, } \\
& \text { UV-exposed site. }
\end{aligned}
$$

\section{Histopathology}

MCC usually appears as a dermal tumor nodule, which frequently extends into the subcutaneous fatty tissue. The tumor cells are small blue cells with basophilic nuclei and minimal cytoplasm. Mitoses are frequent and the apoptosis index is high [15]. The papillary dermis and adnexa are usually spared [16]. 


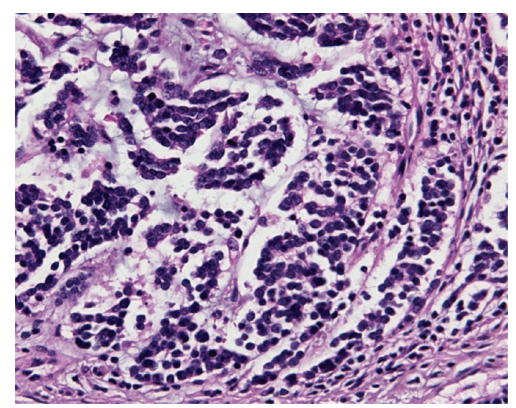

(a)

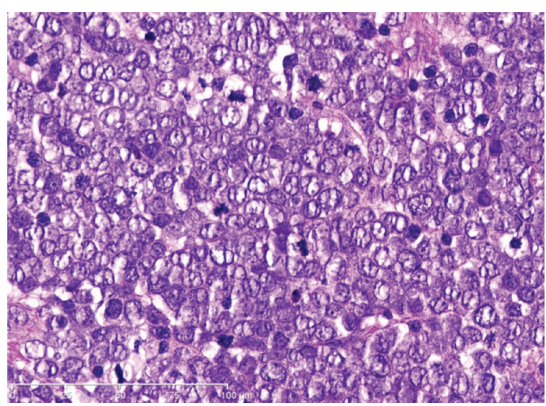

(b)

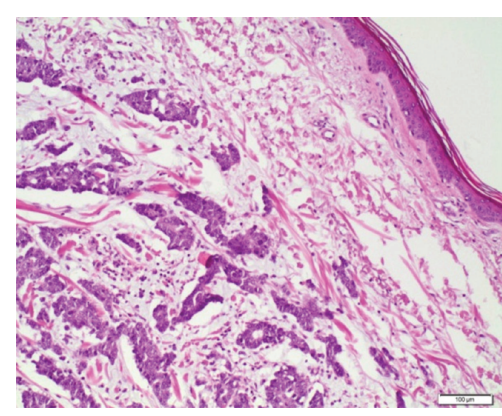

(c)

FIGURE 1: (a) Small-cell variant, histologically indistinguishable from bronchial small-cell carcinoma. (b) Intermediate variant of MCC showing vesicular, basophilic nuclei with prominent nucleoli and high mitotic activity. (c) Trabecular variant is rare and normally only seen as a small component of a mixed variant.

Three histologic subtypes (showen by Figure 1) have been recognized $[4]$ :
(a) the intermediate type,
(b) the small cell type,
(c) the trabecular type.

In the latest data the trabecular form is discussed as the best differentiated with a better prognosis, while the small cell form is relatively undifferentiated and has a worse prognosis. But comprehensive data are missing and mixed and transitional forms are frequent, so there is no clear histologicprognostic association.

Tumor size $\leq 2 \mathrm{~cm}$, female gender, primary tumour localized at the upper limb, and pathologically proven negative lymph nodes are factors highly significant for prognosis and are incorporated into the new staging system for MCC [6, 19].

Andea et al. evaluated retrospectively the following histologic features with regard to prognosis: tumor thickness, microanatomic compartment involved by tumor (dermis and/or subcutis and/or deeper), tumor growth pattern (nodular circumscribed versus infiltrative), lymphovascular invasion, tumor-infiltrating lymphocytes, tumor necrosis, ulceration, and solar elastosis. On multivariate analysis, tumor thickness, the presence of a nodular growth pattern, low tumor depth and absence of lymphovascular invasion were statistically significantly associated with longer survival [20].

Morphometric analyses revealed that Merkel cell polyomavirus-negative Merkel cell carcinomas show a different histologic appearance with more irregular nuclei and more abundant cytoplasm than Merkel cell polyomavirus-positive Merkel cell carcinomas, which are characterized by uniform round nuclei and scant cytoplasm [21].

\section{Immunohistochemistry}

The "small round blue cell" histologic pattern of MCC must be differentiated from several other tumors, such as smallcell lung carcinoma, carcinoid tumor, malignant lymphoma, and small-cell melanoma. Therefore immunohistochemical stainings are required. MCCs are positive for epithelial and neuroendocrine markers, but are negative for lymphoid and melanoma markers [15]. Table 1 shows characteristic immunohistochemical staining patterns for these entities.

Positive staining for CK20 and NSE are quite specific for MCC. Anti-cytokeratin 20 (CK20) staining is concordant to data from the previous literature showing "paranuclear dot-like pattern" in 97\% of all included MCCs [7]. This highly sensitive staining feature is very important for routine histopathology to distinguish MCCs from other small round blue cell tumors $[22,23]$.

Thyroid transcription factor-1 (TTF-1) is usually expressed in small-cell lung carcinoma but is consistently absent in MCC [7]. Leucocyte common antigen (LCA) is negative in MCC, but positive in lymphoma [18, 24]. Small cell carcinoma of the lung (SCLC) is cytokeratin 7 (CK7) positive, but not MCC [22].

Another useful marker for the distinction between MCC and small-cell lung carcinoma is the neurofilament protein (NFP), which is usually positive in MCC and always negative in small-cell lung carcinoma [22].

The differentiation between MCC and malignant melanoma is based on the negativity of the latter for CK 20 and its positivity for HBM45, NKI/C3, and S-100, for which MCC is usually negative [25].

Further, the tumor cells of MCC display additional antigens in varying frequency and intensity; these include, among others, chromogranin A, synaptophysin, tenascin-C, CD56 as well as various neurofilaments and neuropeptides. Expression of the inhibitor of apoptosis (IAP) survivin and the member of the p53 family p63 appears to be associated with a poorer prognosis [17, 26-28].

\section{Merkel Cell Polyomavirus}

Although MCC is one of the most aggressive skin cancers with a high mortality rate, little is known about potential signalling mechanism that drives carcinogenesis in MCC. The association of MCC with immunosuppression has prompted the hypothesis of a viral implication in the pathogenesis of the tumor. But the published data on the impact of 
TABLE 1: Immunohistochemistry of Merkel cell carcinoma (according to Schrama et al. 2011, Becker et al. 2008; [17, 18]). CK20: cytokeratin 20; CK7: cytokeratin 7; NSE: neuron-specific enolase; TTF1: thyorid transcriptor factor 1; LCA: leucocyte common antigen.

\begin{tabular}{lccccc}
\hline & CK20 & CK7 & NSE & TTF1 & S100 \\
\hline Merkel cell carcinoma (MCC) & + & - & + & - & - \\
Small cell carcinoma of the lung & - & + & + & + & - \\
(SCLC) & - & - & - & - & - \\
Melanoma & - & - & - & - & - \\
Lymphoma & & & & - \\
\hline
\end{tabular}

Merkel cell polyomavirus (MCPyV) presence or viral load on prognosis remain controversial.

Merkel cell Polyomavirus (MCPyV) was identified in January 2008 by Feng and colleagues in tumor tissue from MCC patients, proving clonal integration of the virus DNA into the host genome [25]. Meanwhile several studies confirmed this observation showing frequent prevalence of MCPyV DNA in MCCs [29-35]. These data suggest MCPyV as the likely causative agent of MCC. It is supposed that an interaction of the MCC virus protein with p53 and members of the retinoblastoma ( $\mathrm{Rb}-$ ) Gen family could be responsible for the malignant degradation $[30,36]$.

Furthermore, Sihto et al. found evidence for better prognosis in MCPyV DNA-positive MCC having fewer regional nodal metastasis at time of diagnosis compared to MCPyV DNA-negative MCC [34]. Andres et al. showed that MCPyV DNA-positive MCCs tend to be preferentially located on the limbs and tend to metastasize less frequently [37]. It seems that MCPyV MCCs harbour more genomic aberrations than MCPyV ones [38]. Besides it has been reported that absence of $\mathrm{MCPyV}$ or lower viral abundance is associated with increased p53 and KIT espression [39, 40]. Meanwhile, latest data did not show better clinical prognosis in patients with MCPyV-positive MCCs [2, 25].

\section{CK20-, CK19-, CD117-, and ST-3 Protein Expression of Tumor Cells as a Function of Presence of MCPyV DNA in MCC}

There is only one report analyzing immunohistochemical features of MCCs in correlation to presence of MCPyV DNA [41]. In the cohort studied there is no statistical significant association between MCPyV DNA prevalence and immunohistochemical expression of CK20, CK19, CD117, and ST3 was detected but some exciting trends.

CK 19 is a small human cytokeratin, expressed in undifferentiated germinative basaloid cells and usually not expressed by cells of nonepithelial origin [42]. CD117 is a transmembrane protein of the receptor tyrosine kinase family. Stromeylsin-3/matrix metalloproteinase11 (ST3) overexpression could be associated with tumor invasion because of a antiapoptotic effects [43]. A more frequent CK19 expression in MCPyV DNA-negative MCCs and CD117 expression in MCPyV DNA-positive MCCs was observed. Moreover, CK19 is a helpful diagnostic marker for CK20-negative MCC. The role of ST3 expression is not yet clear, being expressed by the MCC tumor cells themselves in about half of all cases, independent of MCPyV DNA-prevalence. However, in some studies MCPyV DNA-prevalence seems to influence the biological behavior of MCCs, resulting in better overall survival for patients with positive MCPyV DNA-status [34]. Most probably due to different invasion and metastatic properties, Andres et al. were not able to find statistically significant differences in the expression pattern of CK20, CK19, CD117, and ST3 [41].

In conclusion, more data will be needed to get profound insight in the carcinogenesis of MCC. As MCC is a rare cancer, studies are limited and further molecular studies are required as well as clinical investigations to establish the impact of MCPyV on MCC which perhaps could open new therapetic options.
Abbreviations
CK7: $\quad$ Cytokeratin 7
CK 20: Cytokeratin 20
LCA: Leucocyte common antigen
MCC: Merkel cell carcinoma
MCPyV: Merkel cell Polyomavirus
NSE: Neuron-specific enolase
TTF-1: Thyroid transcription factor-1
SCLC: Small cell carcinoma of the lung.

\section{References}

[1] M. H. Swann and J. Yoon, "Merkel cell carcinoma," Seminars in Oncology, vol. 34, no. 1, pp. 51-56, 2007.

[2] J. R. Rubel, E. L. Milford, and R. Abdi, "Cutaneous neoplasms in renal transplant recipients," European Journal of Dermatology, vol. 12, no. 6, pp. 532-535, 2002.

[3] E. A. Engels, M. Frisch, J. J. Goedert, R. J. Biggar, and R. W. Miller, "Merkel cell carcinoma and HIV infection," Lancet, vol. 359, no. 9305, pp. 497-498, 2002.

[4] C. K. Bichakjian, L. Lowe, C. D. Lao et al., "Merkel cell carcinoma: critical review with guidelines for multidisciplinary management," Cancer, vol. 110, no. 1, pp. 1-12, 2007.

[5] K. M. Morrison, G. R. Miesegaes, E. A. Lumpkin, and S. M. Maricich, "Mammalian Merkel cells are descended from the epidermal lineage," Developmental Biology, vol. 336, no. 1, pp. 76-83, 2009.

[6] J. Albores-Saavedra, K. Batich, F. Chable-Montero, N. Sagy, A. M. Schwartz, and D. E. Henson, "Merkel cell carcinoma demographics, morphology, and survival based on 3870 cases: a population based study," Journal of Cutaneous Pathology, vol. 37 , no. 1 , pp. 20-27, 2010. 
[7] A. L. Dancey, S. S. Rayatt, C. Soon, A. Ilchshyn, I. Brown, and S. Srivastava, "Merkel cell carcinoma: a report of 34 cases and literature review," Journal of Plastic, Reconstructive and Aesthetic Surgery, vol. 59, no. 12, pp. 1294-1299, 2006.

[8] M. Poulsen, "Merkel cell carcinoma of skin: diagnosis and management strategies," Drugs and Aging, vol. 22, no. 3, pp. 219-229, 2005.

[9] S. S. Yom, D. I. Rosenthal, A. K. El-Naggar, M. S. Kies, and A. C. Hessel, "Merkel cell carcinoma of the tongue and head and neck oral mucosal sites," Oral Surgery, Oral Medicine, Oral Pathology, Oral Radiology and Endodontology, vol. 101, no. 6, pp. 761-768, 2006.

[10] N. M. Coleman, M. J. Smith-Zagone, J. Tanyi et al., "Primary neuroendocrine carcinoma of the vagina with Merkel cell carcinoma phenotype," American Journal of Surgical Pathology, vol. 30, no. 3, pp. 405-410, 2006.

[11] C. Andres, M. J. Flaig, and B. Belloni, "Red, glassy tumor in the lower leg: highly malignant," Fortschritte der Medizin, vol. 152 , no. 15 , p. $5,2010$.

[12] W. Goessling, P. H. McKee, and R. J. Mayer, "Merkel cell carcinoma," Journal of Clinical Oncology, vol. 20, no. 2, pp. 588-598, 2002.

[13] C. Andres, U. Puchta, and M. J. Flaig, "Detection of merkel cell polyomavirus DNA in atypical fibroxanthoma in correlation to clinical features," American Journal of Dermatopathology, vol. 32, no. 8, pp. 799-803, 2010.

[14] M. Heath, N. Jaimes, B. Lemos et al., "Clinical characteristics of Merkel cell carcinoma at diagnosis in 195 patients: the AEIOU features," Journal of the American Academy of Dermatology, vol. 58, no. 3, pp. 375-381, 2008.

[15] T. W. McCardle, V. K. Sondak, J. Zager, and J. L. Messina, "Merkel cell carcinoma: pathologic findings and prognostic factors," Current Problems in Cancer, vol. 34, no. 1, pp. 47-64, 2010.

[16] T. Y. Eng, M. G. Boersma, C. D. Fuller et al., "A comprehensive review of the treatment of Merkel cell carcinoma," American Journal of Clinical Oncology, vol. 30, no. 6, pp. 624-636, 2007.

[17] D. Schrama, W. K. Peitsch, M. Zapatka et al., "Merkel cell polyomavirus status is not associated with clinical course of merkel cell carcinoma," Journal of Investigative Dermatology, vol. 131, no. 8, pp. 1631-1638, 2011.

[18] J. C. Becker, C. S. Kauczok, S. Ugurel, S. Eib, E. B. Bröcker, and R. Houben, "Merkel cell carcinoma: molecular pathogenesis, clinical features and therapy," Journal of the German Society of Dermatology, vol. 6, no. 9, pp. 709-720, 2008.

[19] B. D. Lemos, B. E. Storer, J. G. Iyer et al., "Pathologic nodal evaluation improves prognostic accuracy in Merkel cell carcinoma: analysis of 5823 cases as the basis of the first consensus staging system," Journal of the American Academy of Dermatology, vol. 63, no. 5, pp. 751-761, 2010.

[20] A. A. Andea, D. G. Coit, B. Amin, and K. J. Busam, "Merkel cell carcinoma: histologic features and prognosis," Cancer, vol. 113, no. 9, pp. 2549-2558, 2008.

[21] S. Kuwamoto, H. Higaki, K. Kanai et al., "Association of Merkel cell polyomavirus infection with morphologic differences in Merkel cell carcinoma," Human Pathology, vol. 42, no. 5, pp. 632-640, 2011.

[22] M. Bobos, P. Hytiroglou, I. Kostopoulos, G. Karkavelas, and C. S. Papadimitriou, "Immunohistochemical distinction between Merkel cell carcinoma and small cell carcinoma of the lung," American Journal of Dermatopathology, vol. 28, no. 2, pp. 99-104, 2006.

[23] E. Acebo, N. Vidaurrazaga, C. Varas, J. J. Burgos-Bretones, and J. L. Díaz-Pérezt, "Merkel cell carcinoma: a clinicopathological study of 11 cases," Journal of the European Academy of Dermatology and Venereology, vol. 19, no. 5, pp. 546-551, 2005.

[24] J. Becker, C. Mauch, R. D. Kortmann et al., "Short German guidelines: Merkel cell carcinoma," Journal of the German Society of Dermatology, vol. 6, no. 1, pp. S16-S18, 2008.

[25] G. J. Kontochristopoulos, P. G. Stavropoulos, K. Krasagakis, S. Goerdt, and C. C. Zouboulis, "Differentiation between Merkel cell carcinoma and malignant melanoma: an immunohistochemical study," Dermatology, vol. 201, no. 2, pp. 123-126, 2000.

[26] S. Asioli, A. Righi, M. Volante, V. Eusebi, and G. Bussolati, "p63 expression as a new prognostic marker in Mrkel cell carcinoma," Cancer, vol. 110, no. 3, pp. 640-647, 2007.

[27] J. Kim and J. M. McNiff, "Nuclear expression of survivin portends a poor prognosis in Merkel cell carcinoma," Modern Pathology, vol. 21, no. 6, pp. 764-769, 2008.

[28] M. G. Tucci, G. Lucarini, M. Giangiacomi et al., "Immunohistochemical study of apoptosis markers and involvement of chemokine CXCR4 in skin Merkel cell carcinoma," Journal of the European Academy of Dermatology and Venereology, vol. 20, no. 10, pp. 1220-1225, 2006.

[29] C. Andres, B. Belloni, U. Puchta, C. A. Sander, and M. J. Flaig, "Prevalence of MCPyV in Merkel cell carcinoma and nonMCC tumors," Journal of Cutaneous Pathology, vol. 37, no. 1, pp. 28-34, 2010.

[30] J. C. Becker, R. Houben, S. Ugurel, U. Trefzer, C. Pföhler, and D. Schrama, "MC polyomavirus is frequently present in Merkel cell carcinoma of European patients," The Journal of investigative dermatology, vol. 129, no. 1, pp. 248-250, 2009.

[31] V. Foulongne, N. Kluger, O. Dereure, N. Brieu, B. Guillot, and M. Segondy, "Merkel cell polyomavirus and Merkel cell carcinoma, France," Emerging Infectious Diseases, vol. 14, no. 9, pp. 1491-1493, 2008.

[32] K. M. Garneski, A. H. Warcola, Q. Feng, N. B. Kiviat, J. H. Leonard, and P. Nghiem, "Merkel cell polyomavirus is more frequently present in North American than Australian Merkel cell carcinoma tumors," Journal of Investigative Dermatology, vol. 129, pp. 246-248, 2009.

[33] A. Kassem, A. Schöpflin, C. Diaz et al., "Frequent detection of merkel cell polyomavirus in human merkel cell carcinomas and identification of a unique deletion in the VP1 gene," Cancer Research, vol. 68, no. 13, pp. 5009-5013, 2008.

[34] H. Sihto, H. Kukko, V. Koljonen, R. Sankila, T. Böhling, and H. Joensuu, "Clinical factors associated with merkel cell polyomavirus infection in merkel cell carcinoma," Journal of the National Cancer Institute, vol. 101, no. 13, pp. 938-945, 2009.

[35] J. Mangana, P. Dziunycz, K. Kerl, R. Dummer, and A. Cozzio, "Prevalence of merkel cell polyomavirus among Swiss Merkel cell carcinoma patients," Dermatology, vol. 221, no. 2, pp. 184$188,2010$.

[36] U. Moens, M. van Ghelue, and M. Johannessen, "Oncogenic potentials of the human polyomavirus regulatory proteins," Cellular and Molecular Life Sciences, vol. 64, no. 13, pp. 16561678, 2007.

[37] C. Andres, B. Belloni, U. Puchta, C. A. Sander, and M. J. Flaig, "Re: clinical factors associated with merkel cell polyomavirus infection in merkel cell carcinoma," Journal of the National Cancer Institute, vol. 101, no. 23, pp. 1655-1656, 2009.

[38] K. G. Paulson, B. D. Lemos, B. Feng et al., "Array-CGH reveals recurrent genomic changes in merkel cell carcinoma including amplification of L-Myc," Journal of Investigative Dermatology, vol. 129, no. 6, pp. 1547-1555, 2009. 
[39] K. Bhatia, J. J. Goedert, R. Modali, L. Preiss, and L. W. Ayers, "Merkel cell carcinoma subgroups by Merkel cell polyomavirus DNA relative abundance and oncogene expression," International Journal of Cancer, vol. 126, no. 9, pp. 2240-2246, 2010.

[40] M. Waltari, H. Sihto, H. Kukko et al., "Association of Merkel cell polyomavirus infection with tumor p53, KIT, stem cell factor, PDGFR-alpha and survival in Merkel cell carcinoma," International Journal of Cancer, vol. 129, no. 3, pp. 619-628, 2011.

[41] C. Andres, B. Belloni, T. Jaeger et al., "Immunohistochemical features of merkel cell carcinoma in correlation with presence of merkel cell polyomavirus DNA," Acta DermatoVenereologica, vol. 91, no. 6, pp. 722-723, 2011.

[42] M. Michel, N. Török, M. J. Godbout et al., "Keratin 19 as a biochemical marker of skin stem cells in vivo and in vitro: keratin 19 expressing cells are differentially localized in function of anatomic sites, and their number varies with donor age and culture stage," Journal of Cell Science, vol. 109, no. 5, pp. 1017-1028, 1996.

[43] M. C. Rio, "From a unique cell to metastasis is a long way to go: clues to stromelysin-3 participation," Biochimie, vol. 87, no. 34, pp. 299-306, 2005. 


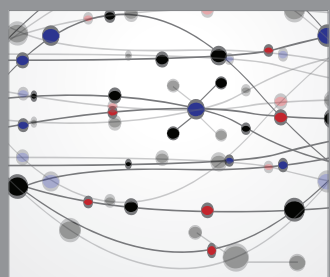

The Scientific World Journal
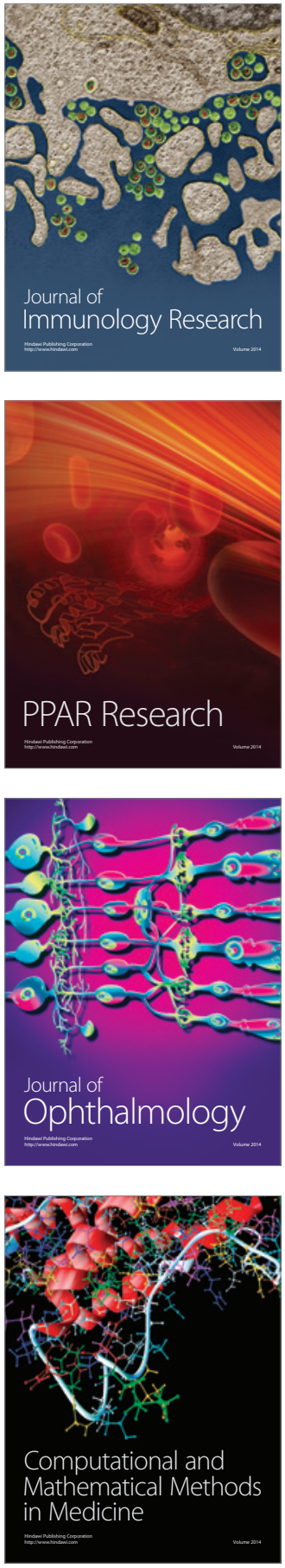

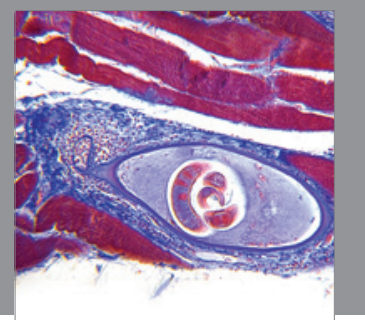

Gastroenterology

Research and Practice
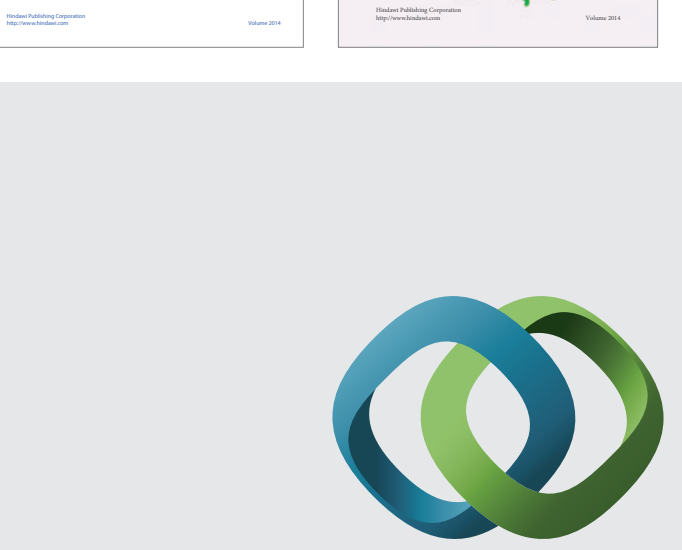

\section{Hindawi}

Submit your manuscripts at

http://www.hindawi.com
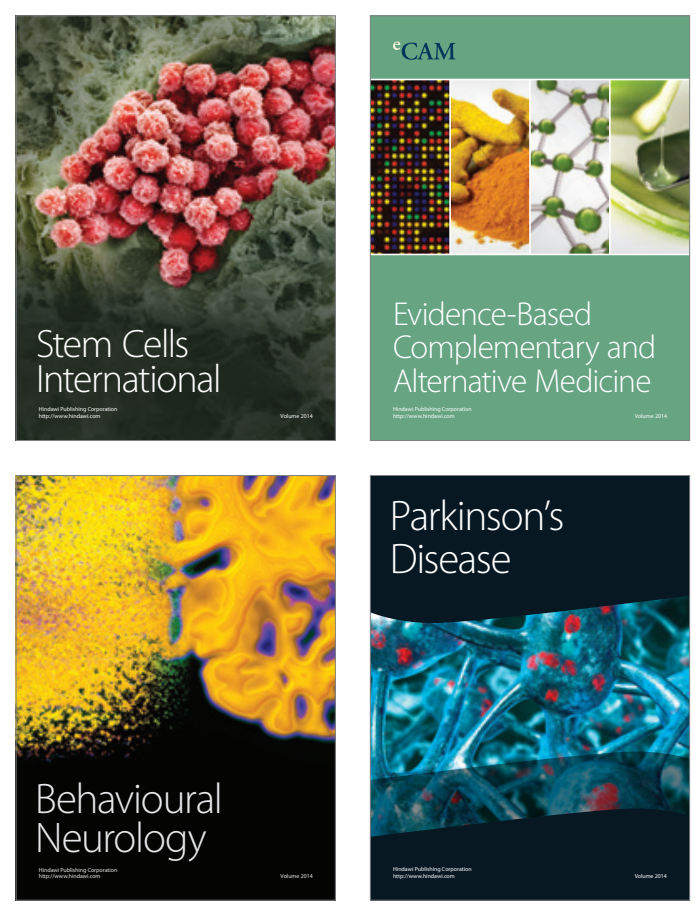

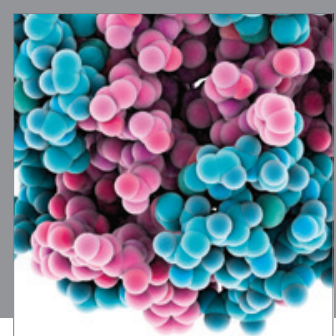

Journal of
Diabetes Research

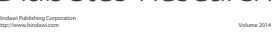

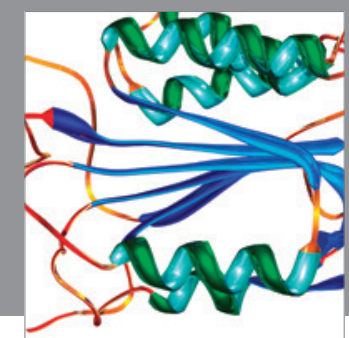

Disease Markers
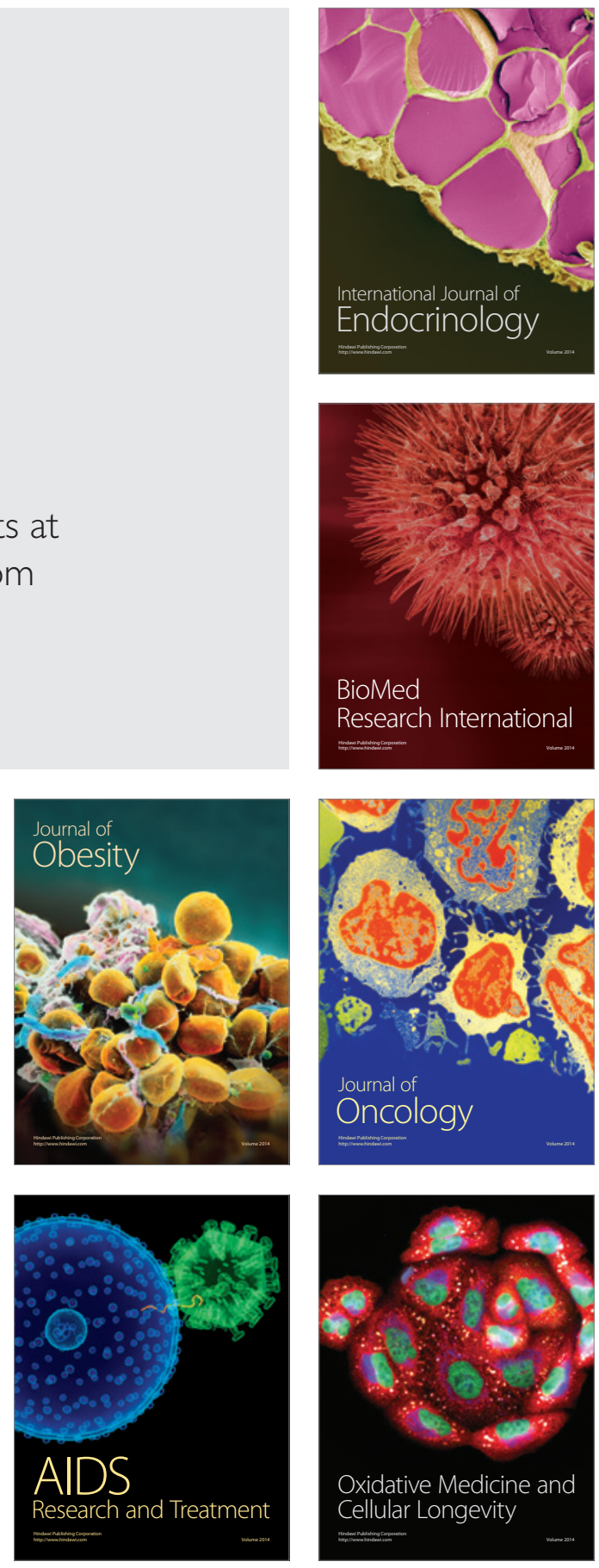